\title{
Soil pH governs production rate of calcium carbonate secreted by the earthworm Lumbricus terrestris
}

Article

Accepted Version

Lambkin, D. C., Gwilliam, K. H., Layton, C., Canti, M. G., Piearce, T. G. and Hodson, M. E. (2011) Soil pH governs production rate of calcium carbonate secreted by the earthworm Lumbricus terrestris. Applied Geochemistry, 26 (Supple). S64-S66. ISSN 0883-2927 doi:

https://doi.org/10.1016/j.apgeochem.2011.03.032 Available at https://centaur.reading.ac.uk/20339/

It is advisable to refer to the publisher's version if you intend to cite from the work. See Guidance on citing.

To link to this article DOI: http://dx.doi.org/10.1016/j.apgeochem.2011.03.032

Publisher: Elsevier

All outputs in CentAUR are protected by Intellectual Property Rights law, including copyright law. Copyright and IPR is retained by the creators or other copyright holders. Terms and conditions for use of this material are defined in the End User Agreement. 


\section{CentAUR}

Central Archive at the University of Reading

Reading's research outputs online 
1 Soil $\mathrm{pH}$ governs production rate of calcium carbonate secreted by the earthworm Lumbricus

2 terrestris

3

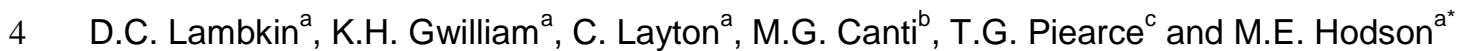
5

$6 \quad{ }^{a}$ Soil Research Centre, School of Human and Environmental Sciences, University of $7 \quad$ Reading, Whiteknights, Reading, RG6 6DW

8 b English Heritage, Ancient Monuments Laboratory, Centre for Archaeology, Fort 9 Cumberland, Eastney, PO4 9LD, UK

$10{ }^{\mathrm{c}}$ Lancaster Environment Centre, Lancaster University, LA1 4YQ, UK 11

* corresponding author. m.e.hodson@reading.ac.uk 


\section{ABSTRACT}

Lumbricus terrestris earthworms exposed to 11 soils of contrasting properties produced, on average, $0.8 \pm 0.1 \mathrm{mg}_{\text {calcite }}$ earthworm ${ }^{-1} \mathrm{day}^{-1}$ in the form of granules up to $2 \mathrm{~mm}$ in diameter Production rate increased with soil $\mathrm{pH}\left(\mathrm{r}^{2}=0.68, \mathrm{p} \leq 0.01\right)$. Earthworms could be a significant source of calcite in soils.

\section{INTRODUCTION}

Earthworms secrete granules of calcium carbonate, predominantly calcite but also aragonite, vaterite and amorphous calcium carbonate (Gago-Duport et al., 2008; Lee et al. 2008). The granules are produced in the calciferous glands of the earthworm. In the case of L. terrestris these occur in segments 10,11 and 12 as three pairs of swellings off the oesophagus. Micron-scale "spherites" of amorphous calcium carbonate are secreted in the rear two pairs of oesophagal glands and move forwards into a pair of oesophagal pouches, by which time they have largely crystallised to calcite and have combined to form granules. The granules are secreted from the oesophagal pouches through a sphincter into the oesophagus. The function that these granules serve for the earthworm is unknown (Darwin, 1881; Robertson, 1936; Piearce, 1972; Briones et al., 2008) but previous studies have shown that earthworm granules are commonplace in soils (Ponomareva, 1948; Wiecek and Messenger, 1972; Bal, 1977; Canti, 1998). On the basis of field measurements Wiecek and Messenger (1972) estimated that excreted calcium carbonate could contribute up to $11 \mathrm{~mol}_{\mathrm{CaCO}} \mathrm{ha}^{-1} \mathrm{yr}^{-1}$ to forest soils. Canti and Piearce (2003) determined that granule production rates were greatest for the earthworms Lumbricus terrestris and L. rubellus. Canti (2007) estimated production rates of $2.2 \mathrm{mg}_{\text {calcite }}$ day $^{-1}$ earthworm ${ }^{-1}$ for L. terrestris. The aim of the study reported here was to determine how granule production rate of $L$. terrestris varied with soil properties.

\section{METHODS}

Eleven soils were collected, air-dried, sieved to $<250 \mu \mathrm{m}$ and characterised (Table 1). In all production experiments one (weighed) clitellate L. terrestris was added to moist soil (300 g air dry soil plus sufficient deionised water to raise the soil to $65 \%$ of its water holding capacity). Moisture content was kept constant throughout the experiment by addition of deionised water 
1 if treatments lost weight. Treatments were kept at $18^{\circ} \mathrm{C}$ under ambient light conditions. At the end of each experiment the earthworm was removed and weighed prior to release. The soil was wet-sieved to $500 \mu \mathrm{m}$ to recover freshly produced granules from the soil. These were air dried and weighed.

In our first experiment earthworms were exposed to the 11 different soils for 27 days with six replicates per treatment. Three grammes of horse manure were added to each earthworm container at the start of the experiment. In a second experiment eight earthworms were each separately and repeatedly exposed to Hamble soil for periods of 39 - 57 days. After each exposure period granules were extracted from the soil, earthworms were weighed and then transferred to fresh Hamble soil. This process was repeated a total of seven times over 315 days. Three grammes of horse manure were added to each container every 14 days. Data were checked for normality and equality of variance. In the first experiment treatments were compared using Kruskall-Wallis one-way analysis of variance on ranks and Dunn's method for pairwise comparisons. In the second experiment reported correlations are Pearson correlations. All statistical analysis used SigmaStat for Windows 3.01 produced by SPSS inc. In the text values are expressed as mean \pm standard error.

\section{RESULTS}

At the end of the first experiment one earthworm had escaped or died from the Coombe Complex, Kettering Loam, Neville, Park Gate and St Albans Wood soils and two from the Hamble replicates. Granule production varied both within and between soils $(p \leq 0.01)$ (Fig. 1). Within individual soils there was on average a factor of $7.7 \pm 2.2(n=10$, St Albans Wood data discounted due to an absence of granules) times difference in masses of granules produced by individual earthworms in the six replicate containers. Across all soils, granule production rate varied between 0 in the $\mathrm{pH} 4.3 \mathrm{St}$ Albans Wood soil (the next lowest production rate was $0.05 \mathrm{mg}_{\mathrm{CaCO} 3}$ earthworm ${ }^{-1}$ day $^{-1}$ in one of the $\mathrm{pH} 6.1$ Wilderness soil replicates) and $4.3 \mathrm{mg}_{\text {calcite }}$ earthworm ${ }^{-1}$ day $^{-1}$ (in one of the Coombe Complex soil replicates, $\mathrm{pH}$ 7.8). Average production rate for all soils was $0.8 \pm 0.1 \mathrm{mg}_{\mathrm{CaCO} 3}$ earthworm ${ }^{-1} \mathrm{day}^{-1}(\mathrm{n}=$ 57). Of the soil properties listed in Table 1, granule production rate was strongly correlated 
1 with $\mathrm{pH}\left(\mathrm{r}^{2}=0.68, \mathrm{p} \leq 0.01\right)$ but none of the other measured soil properties.

2

3

In the second experiment, over the 315 days two deaths occurred (between adjacent sampling dates of 81 and 123 days) and the earthworms lost weight from an initial $5.3 \pm 0.5 \mathrm{~g}$ $(n=8$,$) to 2.4 \pm 0.3 \mathrm{~g}(n=6)$ at the end of the experiment. There was a significant correlation between production rate and earthworm mass $(r=0.62, p \leq 0.01)$. Three individual earthworms (earthworms 1, 3 and 5), which showed a significant correlation between granule production and earthworm mass $(r=0.65$ to $0.92, p \leq 0.01)$, also showed a significant negative correlation between granule production and time $(r=-0.78$ to $-0.93, p \leq 0.01)$ (Fig. 2). On average granule production rate, expressed on a $\mathrm{mg}_{\text {calcite }}$ earthworm ${ }^{-1}$ day $^{-1}$ basis, varied between earthworms by a factor of $3.4 \pm 0.6(n=6)$; normalising to earthworm mass (i.e. $\mathrm{mg}_{\text {calcite }} \mathrm{g}^{-1}$ earthworm day $^{-1}$ ) did not significantly reduce this level of variation $(3.3 \pm 0.5)$.

\section{DISCUSSION}

Granule production rate shows significant variation between earthworms and between soils. The variation, at least in part, appears to reflect naturally occurring biological variation between individual earthworms with larger earthworms producing more granules. However, there are significant differences in production rates between soils, which indicates that some of the variation is due to differences in soil properties. Whilst the correlation between production rate and $\mathrm{pH}$ potentially reflects dissolution of the granules in the soil, granule dissolution rates are not sufficiently rapid for this to be the case (Lambkin et al., this issue). The hypothesis that the low soil pH lowers the saturation state of calcium carbonate in the earthworm calciferous glands thereby limiting granule production is attractive. However, the oesophagal glands where the granules are initially precipitated as spherites have no direct contact with the soil and it seems unlikely that the fluids from which the spherites precipitate would reflect the soil $\mathrm{pH}$ as they will have a homeostatically regulated $\mathrm{pH}$. Set against this we have observed inclusions of quartz and feldspar in granules (Lee et al. 2008) so there must be some "leakage" of soil material into the calciferous glands, presumably this occurs as the sphincter opens and a granule is expelled from the glands into the oesophagus. Typically in low pH soils there is less $\mathrm{Ca}$ (either total or available) and this could limit granule production. 
1 However, in these experiments there was no discernable relationship between granule production and either total Ca levels in the soil or Ca present on exchange sites. Thus the cause of the relationship between soil $\mathrm{pH}$ and granule production remains unresolved.

An average value for earthworm density is 270 earthworms $\mathrm{m}^{-2}$, which covers a wide range of species in temperature climates (Edwards and Bohlen, 1996); though not all earthworm species produce granules. Using this value, granule production rates reported here of 0.05 to 0.8 to $4.3 \mathrm{mgCaCO}_{3}$ earthworm ${ }^{-1}$ day $^{-1}$ (minimum, average and maximum values) correspond to production rates of 493,7884 and $42377 \mathrm{molCaCO}_{3} \mathrm{ha}^{-1} \mathrm{yr}^{-1}$. A more conservative estimate of 10 to 20 L. terrestris per $\mathrm{m}^{2}$ (Briones et al. 2008) yields production rates of 18 to $3139 \mathrm{molCaCO}_{3} \mathrm{ha}^{-1} \mathrm{yr}^{-1}$ which are more similar to the estimates of Wiecek and Messenger (1972) for forest soils. The precise amount of calcite produced annually by earthworms clearly depends on estimates of earthworm numbers as well as soil properties; however, the production rates of individual earthworms suggests to us that earthworm calcite production is a potentially important source of calcite in soils.

\section{CONCLUSIONS}

Biological variation has a significant impact on the mass of calcium carbonate secreted by earthworms in the form of granules; however, soil properties do play a role as well. The mass of granules produced by earthworms is significant and they are worthy of further study to improve our understanding of their significance in the terrestrial $\mathrm{C}$ cycle.

\section{ACKNOWLEDGEMENTS}

This work was funded by a NERC grant NE/F009623/1 awarded to MEH, TGP and MGC and also a summer studentship for CL funded by the Applied undergraduate research skills CETL hosted by the UoR. We thank Sir William Benyon for permission to collect soil on the Englefield Estate. As ever John Morgan and Pete Kille (Cardiff) provided inspiration through their enthusiasm and interest.

\section{REFERENCES CITED}


Bal, L., 1977. The formation of carbonate nodules and intercalary crystals in the soil by the earthworm Lumbricus rubellus. Pedobiol. 17, 102-106.

Briones, M.J.I., Ostle, N.J., Piearce, T.G., 2008. Stable isotopes reveal that the calciferous gland of earthworms is a $\mathrm{CO}_{2}$-fixing organ. Soil Biol. Biochem. 40, $554-557$.

Canti, M.G., 1998, Origin of calcium carbonate granules found in buried soils and Quaternary deposits: Boreas 27, p. 275-288.

Canti, M.G., 2007, Deposition and taphonomy of earthworm granules in relation to their interpretative potential in Quaternary stratigraphy: J. Quarter. Sci. 22 111-118.

Canti, M.G. and Piearce, T.G., 2003, Morphology and dynamics of calcium carbonate granules produced by different earthworm species: Pedobiol. 47, 511-521.

Darwin, C., 1881, The formation of vegetable mould, through the action of worms, with observations on their habits. John Murray, London.

Edwards, C.A. and Bohlen, P.J., 1996, The biology and ecology of earthworms. Second ed. Chapman and Hall, London.

Gago-Duport, L., Briones, M.J.I., Rodriguez, J.B. and Covelo, B., 2008, Amorphous calcium carbonate biomineralisation in the earthworm's calciferous gland: Pathways to the formation of crystalline phases. J. Struct. Biol. $162422-435$.

Hendershot, W.H. and Duquette, M., 1986, A simple barium chloride method for determining cation exchange capacity and exchangeable cations. Soil Sci. Soc. Am. J. 50, 605-608. Jarvis, R.A., 1968, Soils of the Reading District [Sheet 268]. Memoirs of the Soil Survey of Great Britain, England and Wales: Harpenden, U.K., Rothamsted Experimental Station.

Kay, F.F., 1936, A soil survey of the University farm, Sonning, Berks: Reading, U.K., University of Reading, Faculty of Agriculture and Horticulture, Bulletin XLIX.

Lambkin, D.C., Canti, M.G., Piearce, T.G. and M.E. Hodson (this issue) Dissolution rates of earthworm-secreted calcium carbonate. Appl. Geochem.

Lee, M.R., Hodson, M.E. and Langworthy, G., 2008, Earthworms produce granules of intricately zoned calcite: Geology, 36, 943-946.

MAFF, 1986, Analysis of agricultural materials: A manual of the analytical methods used by the Agricultural Development and Advisory service. Reference Book 427. Third ed. London. 
1 Piearce, T.G., 1972. The calcium relations of selected Lumbricidae: J.Animal Ecol. 41, 167-

2 188.

3 Ponomareva, S.I., 1948, The rate of formation of calcite in the soil by the earthworms. Report of the Academy of Science of the USSR 61, 505-507.

5 Robertson, J.D., 1936, The function of the calciferous glands of earthworms: J. Expt. Biol. 13, $6 \quad 279-297$

7 Wiecek, C.S. and Messenger, A.S., 1972, Calcite contributions by earthworms to forest soils $8 \quad$ in Northern Illinois. Soil Sci. Soc. Am. Proc. 36, 478-480. 
Table 1. Mean chemical characteristics of the $<250 \mu \mathrm{m}$ soils used in experiments expressed in terms of oven dry soil $(n=3 \pm$ standard error except for elemental composition where $n=1)$

\begin{tabular}{|c|c|c|c|c|c|c|c|c|c|c|c|c|c|c|c|c|c|c|c|c|}
\hline \multirow[t]{2}{*}{$\mathrm{Name}^{1}$} & \multirow{2}{*}{$\begin{array}{l}\text { Sample } \\
\text { site }\end{array}$} & \multirow[t]{2}{*}{$\mathrm{pH}$} & \multirow[t]{2}{*}{$\mathrm{LOI}^{3}$} & \multirow[t]{2}{*}{$\mathrm{WHC}^{4}$} & \multirow[t]{2}{*}{$\mathrm{CEC}^{5}$} & \multicolumn{8}{|c|}{ Elemental composition ${ }^{6} /$ wt $\%$} & \multicolumn{7}{|c|}{ Exchangeable ions ${ }^{7} / \mathrm{mg} \mathrm{kg}^{-1}$} \\
\hline & & & & & & $\mathrm{Al}_{2} \mathrm{O}_{3}$ & $\mathrm{CaO}$ & $\mathrm{Fe}_{2} \mathrm{O}_{3}$ & $\mathrm{~K}_{2} \mathrm{O}$ & $\mathrm{MgO}$ & $\mathrm{Na}_{2} \mathrm{O}$ & $\mathrm{P}_{2} \mathrm{O}_{5}$ & $\mathrm{SiO}_{2}$ & $\mathrm{Al}$ & $\mathrm{Ca}$ & $\mathrm{Fe}$ & K & $\mathrm{Mg}$ & $\mathrm{Na}$ & $P$ \\
\hline $\begin{array}{l}\text { Coombe } \\
\text { Complex }\end{array}$ & SU625733 & $\begin{array}{l}7.8 \pm \\
0.0\end{array}$ & $\begin{array}{l}10.2 \\
\pm 0.1\end{array}$ & $\begin{array}{l}54.7 \pm \\
1.8\end{array}$ & $\begin{array}{l}17.2 \pm \\
0.4\end{array}$ & 6 & 39 & 4 & 1 & 3 & 0 & 0 & 45 & $\begin{array}{l}1.1 \pm \\
0.1\end{array}$ & $\begin{array}{l}1933.6 \pm \\
133.6\end{array}$ & 0 & $88,2 \pm 5.9$ & $\begin{array}{l}59.3 \\
\pm 2.4\end{array}$ & $\begin{array}{l}12.0 \\
\pm 2.8\end{array}$ & $\begin{array}{l}36.6 \\
\pm 0.2\end{array}$ \\
\hline Frilsham & SU596726 & $\begin{array}{l}7.0 \pm \\
0.0\end{array}$ & $\begin{array}{l}\overline{7} .7 \pm \\
0.1\end{array}$ & $\begin{array}{l}48.7 \pm \\
1.9\end{array}$ & $\begin{array}{l}16.6 \pm \\
0.2\end{array}$ & 8 & 1 & 3 & 2 & 0 & 0 & 0 & 84 & $\begin{array}{l}1.6 \pm \\
0.0\end{array}$ & $\begin{array}{l}3401.2 \pm \\
9.2\end{array}$ & 0 & $\begin{array}{l}142.5 \pm \\
0.3\end{array}$ & $\begin{array}{l}\overline{7} 8.1 \\
\pm 0.2\end{array}$ & $\begin{array}{l}\overline{9} .3 \pm \\
0.8\end{array}$ & $\begin{array}{l}\overline{5} 0.2 \\
\pm 0.7\end{array}$ \\
\hline Hamble & SU618702 & $\begin{array}{l}7.9 \pm \\
0.0\end{array}$ & $\begin{array}{l}4.2 \pm \\
0.0\end{array}$ & $\begin{array}{l}40.8 \pm \\
0.8\end{array}$ & $\begin{array}{l}10.7 \pm \\
0.1\end{array}$ & 8 & 1 & 3 & 2 & 1 & 0 & 0 & 84 & $\begin{array}{l}1.3 \pm \\
0.0\end{array}$ & $\begin{array}{l}2597.4 \pm \\
15.3\end{array}$ & 0 & $\begin{array}{l}166.2 \pm \\
1.1\end{array}$ & $\begin{array}{l}35.0 \\
\pm 0.2\end{array}$ & $\begin{array}{l}5.9 \pm \\
1.1\end{array}$ & $\begin{array}{l}28.3 \\
\pm 0.1\end{array}$ \\
\hline Kettering & $N / A^{2}$ & $\begin{array}{l}7.4 \pm \\
0.0\end{array}$ & $\begin{array}{l}8.8 \pm \\
0.1\end{array}$ & $\begin{array}{l}53.8 \pm \\
1.0\end{array}$ & $\begin{array}{l}24.5 \pm \\
0.5\end{array}$ & 14 & 2 & 8 & 2 & 1 & 0 & 0 & 71 & $\begin{array}{l}2.1 \pm \\
0.1\end{array}$ & $\begin{array}{l}4948 \pm \\
14\end{array}$ & $\begin{array}{l}0.2 \pm \\
0.0\end{array}$ & $\begin{array}{l}196.9 \pm \\
1.6\end{array}$ & $\begin{array}{l}\overline{1} 25.6 \\
\pm 0.4\end{array}$ & $\begin{array}{l}20.1 \\
\pm 0.8\end{array}$ & $\begin{array}{l}\overline{1} 0.7 \\
\pm 0.4\end{array}$ \\
\hline Neville & SU765754 & $\begin{array}{l}5.4 \pm \\
0.0\end{array}$ & $\begin{array}{l}11.2 \\
\pm 0.1\end{array}$ & $\begin{array}{l}52.0 \pm \\
0.1\end{array}$ & $\begin{array}{l}12.2 \pm \\
0.7\end{array}$ & 6 & 1 & 4 & 2 & 0 & 0 & 1 & 84 & $\begin{array}{l}1.3 \pm \\
0.0\end{array}$ & $\begin{array}{l}2533.7 \pm \\
5.4\end{array}$ & $\begin{array}{l}0.2 \pm \\
0.0\end{array}$ & $\begin{array}{l}473.2 \pm \\
3.4\end{array}$ & $\begin{array}{l}\overline{2} 62.4 \\
\pm 0.4\end{array}$ & $\begin{array}{l}\overline{13} .3 \\
\pm 1.6\end{array}$ & $\begin{array}{l}\overline{1} 02.9 \\
\pm 1.0\end{array}$ \\
\hline Parkgate & SU601684 & $\begin{array}{l}5.6 \pm \\
0.0\end{array}$ & $\begin{array}{l}\overline{8} .5 \pm \\
0.1\end{array}$ & $\begin{array}{l}61.0 \pm \\
2.8\end{array}$ & $\begin{array}{l}15.4 \pm \\
0.3\end{array}$ & 10 & 0 & 4 & 2 & 1 & 0 & 0 & 81 & $\begin{array}{l}1.3 \pm \\
0.0\end{array}$ & $\begin{array}{l}2490.9 \pm \\
3.6\end{array}$ & $\begin{array}{l}0.3 \pm \\
0.0\end{array}$ & $\begin{array}{l}478.0 \pm \\
3.5\end{array}$ & $\begin{array}{l}\overline{3} 03.8 \\
+0.4\end{array}$ & $\begin{array}{l}\overline{1} 9.2 \\
+0.5\end{array}$ & $\begin{array}{l}\overline{7} 9.0 \\
+0.1\end{array}$ \\
\hline $\begin{array}{l}\text { Soil } \\
\text { Science }\end{array}$ & SU731718 & $\begin{array}{l}6.5 \pm \\
0.0\end{array}$ & $\begin{array}{l}19.2 \\
\pm 0.2\end{array}$ & $\begin{array}{l}71.2 \pm \\
1.0\end{array}$ & $\begin{array}{l}37.4 \pm \\
0.1\end{array}$ & 9 & 2 & 6 & 2 & 1 & 0 & 0 & 79 & $\begin{array}{l}89.9 \pm \\
0.8\end{array}$ & $\begin{array}{l}5515.8 \pm \\
17.2\end{array}$ & $\begin{array}{l}88.8 \pm \\
1.7\end{array}$ & $\begin{array}{l}455.2 \pm \\
11.7\end{array}$ & $\begin{array}{l}\overline{3} 12.7 \\
\pm 1.5\end{array}$ & $\begin{array}{l}307.8 \\
\pm 1.9\end{array}$ & $\begin{array}{l}20.4 \\
\pm 0.6\end{array}$ \\
\hline $\begin{array}{l}\text { St Albans } \\
\text { Field }\end{array}$ & SU603716 & $\begin{array}{l}5.1 \pm \\
0.0\end{array}$ & $\begin{array}{l}\overline{1} 0.6 \\
\pm 0.0\end{array}$ & $\begin{array}{l}54.2 \pm \\
1.0\end{array}$ & $\begin{array}{l}13.2 \pm \\
0.2\end{array}$ & 5 & 0 & 2 & 1 & 0 & 0 & 1 & 90 & $\begin{array}{l}16.2 \pm \\
0 . .1\end{array}$ & $\begin{array}{l}2402.2 \pm \\
3.9\end{array}$ & $\begin{array}{l}3.9 \pm \\
0.1\end{array}$ & $\begin{array}{l}262.1 \pm \\
1.8\end{array}$ & $\begin{array}{l}72.4 \\
\pm 0.1\end{array}$ & $\begin{array}{l}\overline{6} .7 \pm \\
0.2\end{array}$ & $\begin{array}{l}\overline{8} 2.3 \\
\pm 0.8\end{array}$ \\
\hline $\begin{array}{l}\text { St Albans } \\
\text { Wood }\end{array}$ & SU602716 & $\begin{array}{l}4.3 \pm \\
0.0\end{array}$ & $\begin{array}{l}\overline{9} 0.2 \\
\pm 1.0\end{array}$ & $\begin{array}{l}143.2 \\
\pm 2.8\end{array}$ & $\begin{array}{l}35.1 \pm \\
0.1\end{array}$ & 10 & 4 & 4 & 2 & 0 & 0 & 1 & 77 & $\begin{array}{l}2.2 \pm \\
0.0\end{array}$ & $\begin{array}{l}5817.0 \pm \\
45.7\end{array}$ & $\begin{array}{l}0.2 \pm \\
0.0\end{array}$ & $\begin{array}{l}400.6 \pm \\
2.6\end{array}$ & $\begin{array}{l}292.7 \\
\pm 2.4\end{array}$ & $\begin{array}{l}43.1 \\
\pm 0.4\end{array}$ & $\begin{array}{l}\overline{3} 4.9 \\
\pm 0.6\end{array}$ \\
\hline Tidmarsh & SU626706 & $\begin{array}{l}7.2 \pm \\
0.0\end{array}$ & $\begin{array}{l}\overline{5} .7 \pm \\
0.1\end{array}$ & $\begin{array}{l}\overline{3} 9.2 \pm \\
0.8\end{array}$ & $\begin{array}{l}14.7 \pm \\
0.6\end{array}$ & 7 & 1 & 3 & 2 & 0 & 0 & 0 & 86 & $\begin{array}{l}1.7 \pm \\
0.2\end{array}$ & $\begin{array}{l}3324.0 \pm \\
487.7\end{array}$ & $\begin{array}{l}0.1 \pm \\
0.0\end{array}$ & $\begin{array}{l}244.7 \pm \\
33.6\end{array}$ & $\begin{array}{l}57.8 \\
+8.5\end{array}$ & $\begin{array}{l}12.8 \\
+1.4\end{array}$ & $\begin{array}{l}\overline{4} 4.0 \\
+0.1\end{array}$ \\
\hline Wilderness & SU738715 & $\begin{array}{l}6.1 \pm \\
0.0\end{array}$ & $\begin{array}{l}27.6 \\
\pm 0.1\end{array}$ & $\begin{array}{l}78.1 \pm \\
1.4\end{array}$ & $\begin{array}{l}42.4 \pm \\
0.1\end{array}$ & 10 & 3 & 5 & 2 & 1 & 0 & 1 & 79 & $\begin{array}{l}2.7 \pm \\
0.1\end{array}$ & $\begin{array}{l}6556.0 \pm \\
7.8\end{array}$ & $\begin{array}{l}0.3 \pm \\
0.01\end{array}$ & $\begin{array}{l}307.1 \pm \\
0.9\end{array}$ & $\begin{array}{l}319.7 \\
\pm 0.3\end{array}$ & $\begin{array}{l}44.3 \\
+0.3 \\
\end{array}$ & $\begin{array}{l}15.4 \\
+0.2\end{array}$ \\
\hline
\end{tabular}

from Broughton Loam and Turf Management, Kettering, UK; ${ }^{3}$ Loss on ignition, \%; ${ }^{4}$ Water holding capacity, $\mathrm{gHzO}_{\mathrm{H}} \mathrm{g}^{-1}$ soil; ${ }^{5} \mathrm{Cation}$ exchange capacity, $\mathrm{cmol}_{\mathrm{c}} \mathrm{kg}^{-1}$ (Hendershot and Duquette, 1986 ); ${ }^{6} \mathrm{By} \mathrm{X}$-ray fluorescence,

normalised to $100 \%{ }^{7}$ Method of Hendershot and Duquette (1986) except P which is Olsen P (MAFF, 1986) 


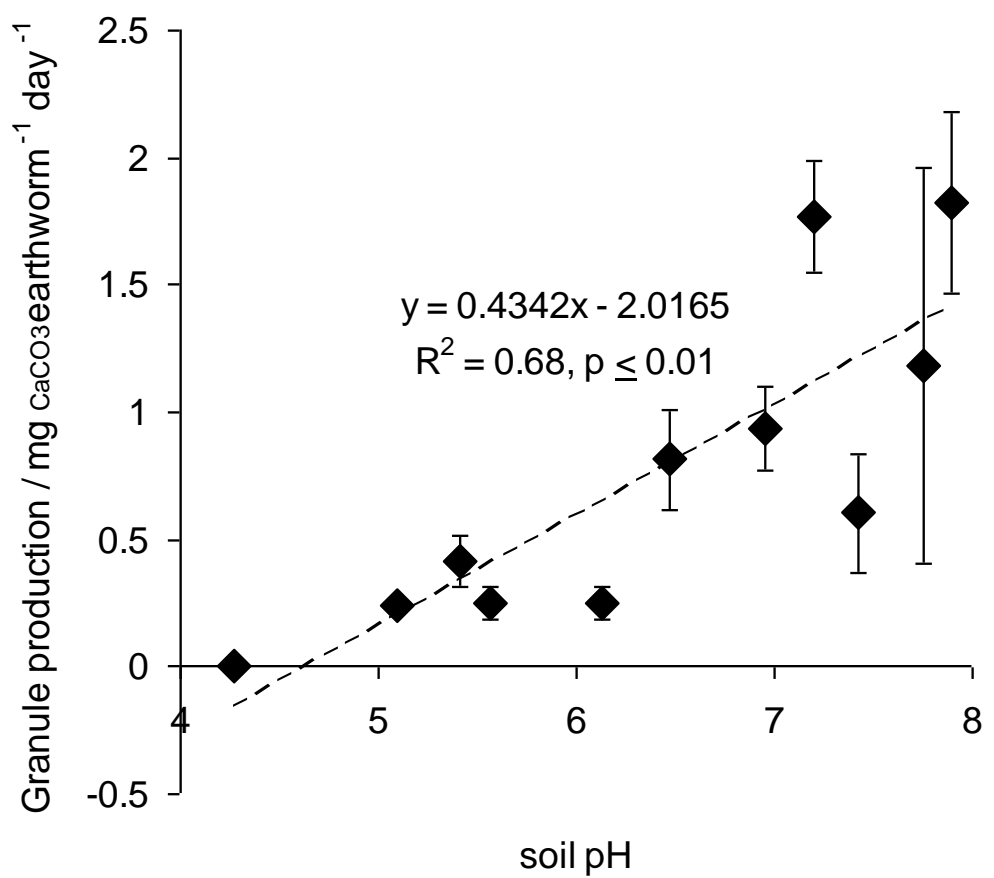

Fig. 1. Mean granule production rate for soils of different $\mathrm{pH}$. Error bars $=$ standard errors, $\mathrm{n}=$ $5-6$.

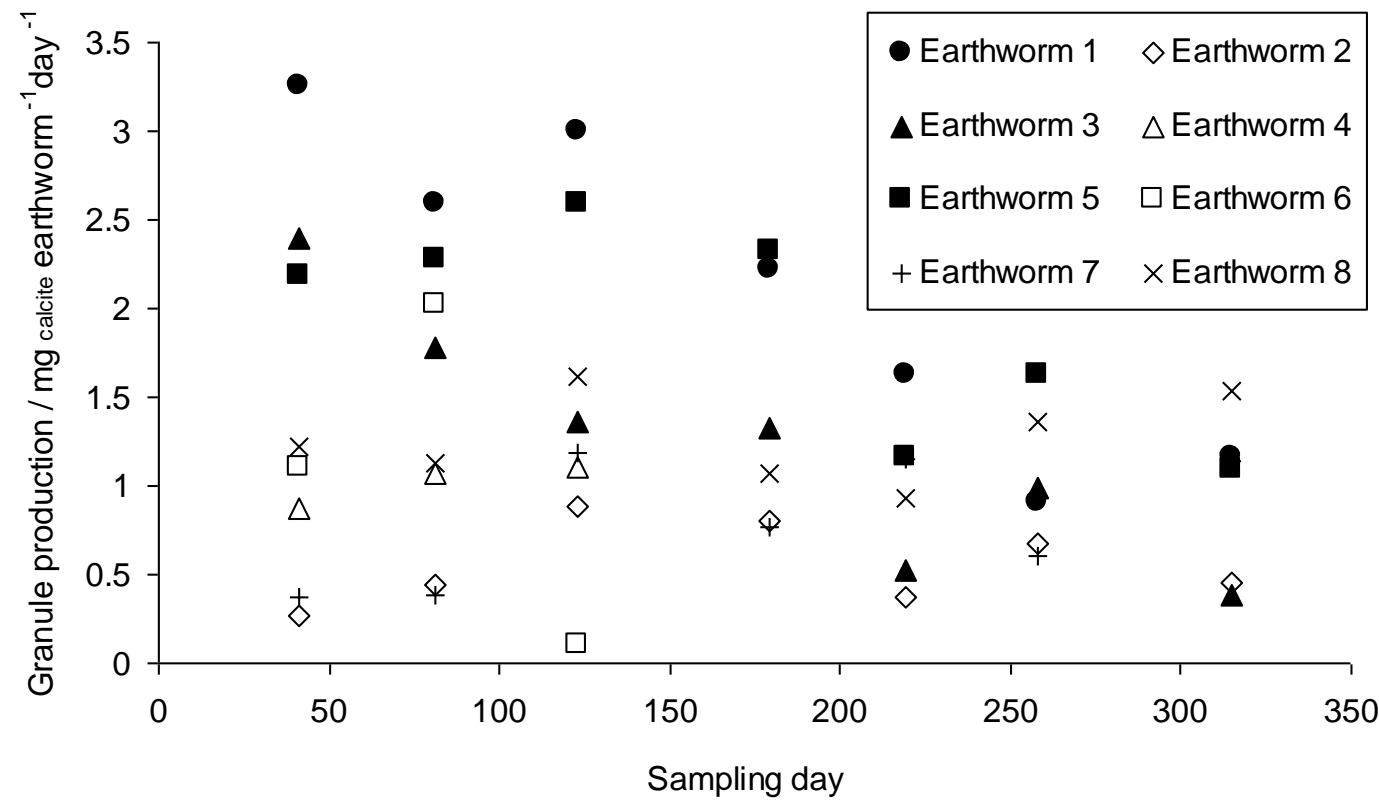

Fig. 2. Granule production rate over time in the Hamble soil. After each sampling date earthworms were put into fresh soil. Earthworms 4 and 6 died at some point between the second (Day 81) and third (Day 123) sampling dates. 